\title{
Alternative dimensions: Lentil \\ Underground: Renegade Farmers and the Future of Food in America
}

Book review by Julia Russell Jozkow *
University of Northern British Columbia

Review of Lentil Underground: Renegade Farmers and the Future of Food in America, by Liz Carlisle. (2015). New York: Penguin Group. 298 pages. Available as hardcover, paperback, and ebook. Publisher's website: http://www.penguin.com/book/lentilunderground-by-liz-carlisle/9781592409204

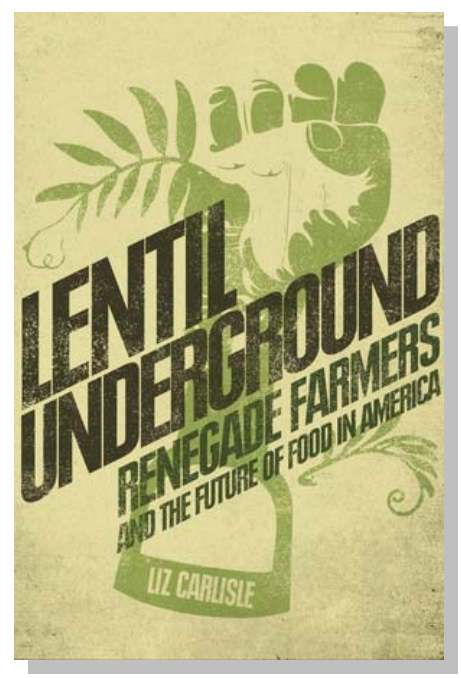

Submitted September 22, 2015 / Published online December 17, 2015

Citation: Russell Jozkow, J. (2015). Alternative dimensions: Lentil Underground: Renegade Farmers and the Future of Food in America [Book review]. Journal of Agriculture, Food Systems, and Community Development, 6(1), 217-219. http://dx.doi.org/10.5304/jafscd.2015.061.019

Copyright (C) 2015 by New Leaf Associates, Inc.

Tentil Underground: Renegade Farmers and the Future Lof Food in America is author Liz Carlisle's first book and is based on ethnographic research she undertook while a doctoral student at the University of California, Berkeley. Carlisle traces the history of organic agriculture in Montana to the present day, with a richly written narrative that makes for an easy read.

* Julia Russell Jozkow, Department of Health Sciences, University of Northern British Columbia; 3333 University Way; Prince George, British Columbia V2N 4Z9 Canada; russe03@,unbc.ca

Julia Russell Jozkow is a graduate student in the School of Health Science at the University of Northern British Columbia. Her research has focused on food access for people during times of homelessness in both Canadian and Bolivian contexts.
In this book Carlisle explores the literal, belowthe-ground workings of nitrogen fixation and legume crops, with lentils taking center stage as the stars of the show. At the same time, Carlisle explores the emergence of a community of tenacious organic farmers centered around Dave Oien, a founding farmer and CEO of Timeless Seeds. Dave Oien serves as the hardworking and tireless hero of this tale.

The author selected the Timeless Seeds growers as a point of interest and resistance in the food system. She examines their work as climatic systems shift, as they navigate systems of governance, and as they connect with buyers, sellers, and consumers. For the Timeless Seeds crew, systems thinking is a central philosophy of their work, so they become engaged in shaping the physical, 
social, and macrolevel environments toward diversity and sustainability.

The challenges that the protagonists have confronted during decades of work remain pertinent issues today, and include farmland buyouts. Carlisle's lively writing tends towards the romantic at times, which obscures the magnitude of the issues the protagonists face. Throughout the book Carlisle hints at significant generational issues in regard to the state of the occupation of farming and the rising average age of a farmer. To highlight this she consistently refers to people in their early to midthirties by the unlikely diminutive of "youngster." She also mentions some of the challenges with succession of the family farm, the high price of farmland that drives it out of range for beginning farmers, and the deterioration of rural communities. Globally these issues are often linked to land grabbing or the concentration of farmland in the hands of large agribusiness.

Carlisle discusses some of the challenges related to dwindling populations of farm families and the work being undertaken to revitalize rural communities. As Carlisle reports, the farmers in this book believe that disconnection from the land is a primary issue. This is a theme that is gaining increasing attention in a range of disciplines, including health care and Indigenous peoples' wellbeing (Parkes, de Leeuw \& Greenwood, 2010; Richmond \& Ross, 2009; Wilson, 2003)

The farmers Carlisle describes in this book are working to share knowledge rather than compete, because they are striving to build a way of living, in addition to earning a living. Yet financial poverty is an undercurrent in this book. Working collectively these farmers can earn a modest income within a capitalist system, where they would otherwise be unable to sustain themselves individually. Ironically, this requires developing niche market products for which consumers are willing to pay a premium; Carlisle does not shy away from discussing issues around lack of affordability of organic foods for low-income people.

Carlisle explains that the challenge of bringing organic produce to market is more than needing a closely knit community of like-minded people, but also needing organic agriculture to be supported at every interval along the food system. She explores how small-scale organic farming may not necessarily operate along the same timeframe on which the markets presently rely, and this requires a reorientation of both consumers' and producers' priorities. Thus the Timeless Seeds farmers face challenges related to remaining true to their ideals while trying to make a living and achieve market success. For example, exploring new methods in sustainable farming techniques requires trial and error, but the errors can result in failed crops and lost contracts.

Carlisle also examines some of the contradictions in modern food movements, including attitudes toward locavore eating and conventionally grown produce. As the author writes about the history of the organic movement in Montana, the reader will come to recognize an ebb and flow in the trendiness of environmentalism, which went out of favor in the early 2000s but is once again gaining traction. Carlisle could have extended her argument by advancing the sustainability aspect further. The potential of legumes is not fully explored in this work and I would have liked to have seen Carlisle push further on not only how as a society we should adapt our farming practices, but also how we can adapt our diets to become more sustainable. In this day and age, one of the most pressing global environmental concerns is climate change. In her argument Carlisle connects climate change and conventional farming, but she primarily discusses produce and does not tackle the meat and dairy industries. She discusses the shortcomings of the locavore movement, and weighs the pros and cons of a local conventional diet in comparison to an organic diet. Carlisle also briefly discusses challenges common in industrial agriculture, such as nitrogen depletion, erosion, and agricultural run-off.

This book emerged from an ethnographic study, and Carlisle richly describes the lives of the people and the culture of organic farming. However, she could explore some themes further. Carlisle aptly describes the challenges faced by farmers (especially organic farmers). Yet her mention of Black Elk without any exploration of his teachings again hints at romanticism and I felt is used as a tool to legitimize the presence of farmers on the land. There is an assumed premise 
that farmers are the rightful inheritors of the land, and there is no acknowledgement of the displacement of Indigenous peoples - the land's original inhabitants and stewards.

At times the narrative is difficult to follow as Carlisle takes the reader on an adventure back and forth through time, compelling one to revisit previous paragraphs in order to clarify during which timeframe events are taking place. However, other seemingly unimportant details are repeated numerous times. In the early pages, when the author is attempting to position herself and connect to the community she is researching, she grasps at weak links that she frames as astounding parallels, such as the age she was when undertaking this research and the age of the protagonist when he started on his organic journey (both at age 27). Canadians may appreciate the links the author makes to agricultural research that took place in that country, and may chuckle as they read about the challenges of "northern" farming that are faced by Canada's southern neighbors.

The appendices are well developed and quite helpful. I would recommend skimming through the appendices before delving into the book, as Carlisle offers detailed explanations of how she crafted her descriptions of protagonists' thoughts and actions that occurred years and sometimes decades before she began her research.
This book takes the reader on a journey that can help to illuminate the human side of farming. Lentil Underground serves as an engaging introduction to some of the multiple compounding challenges that are faced in the movement toward more sustainable agricultural methods, and why there is no such thing as a simple solution. Overall, this was an enjoyable light read that may leave the reader hungry to further explore the subject matter.

\section{References}

Parkes, M. W., de Leeuw, S., \& Greenwood, M. (2010). Warming up to the embodied context of First Nations child health: A critical intervention into and analysis of health and climate change research. International Public Health Journal, 2(4), 477-485. https://www.novapublishers.com/catalog/product info.php?products $\mathrm{id}=22894$

Richmond, C. A. M., \& Ross, N. A. (2009). The determinants of First Nation and Inuit health: A critical population health approach. Health \& Place, 15(2), 403-411. http://dx.doi.org/10.1016/ j.healthplace.2008.07.004

Wilson, K. (2003). Therapeutic landscapes and First Nations peoples: An exploration of culture, health and place. Health \& Place, 9(2), 83-93. http://dx.doi.org/10.1016/S1353-8292(02)00016-3 